\title{
Peran Strategis Lembaga Pendidikan Berbasis Islam di Indonesia
}

\author{
Arief Efendi ${ }^{1}$
}

\begin{abstract}
Abstrak
Pendidikan Islam di Indonesia memang begitu dilematis. Artinya di satu sisi, tuntutan untuk meningkatkan mutu dan kualitas agar dapat bersaing dengan lembaga pendidikan umum, di sisi lain perhatian dari pemerintah terhadap lembaga pendidikan Islam masih rendah bahkan masih ditempatkan bukan sebagai kelas utama (the first class) melainkan sebagai kelas kedua (the second class)

Peningkatan kualitas lembaga pendidikan Islam merupakan keharusan yang perlu segera direalisasikan, mulai dari input, proses dan output atau lulusan dari lembaga pendidikan Islam, SDMpengelola dan para pendidik memiliki peran penting dalam peningkatan kualitas Lembaga Pendidikan Islam.
\end{abstract}

Kata kunci: pendidikan, kualitas, Islam.

\section{A. Pendahuluan}

Salah satu kekeliruan kebijakan pendidikan Nasional yang berpengaruh secara langsung maupun tidak langsung terhadap kinerja pendidikan (educational performance) Indonesia adalah kurang diperhitungkannya lembaga pendidikan Islam dalam sistem pendidikan Nasional. Sekilas ketika kita berbicara masalah peningkatan mutu pendidikan seolah-olah semuanya ditentukan oleh sekolah. Lembaga pendidikan Islam, misalnya madrasah, pondok pesantren maupun sekolah Islam masih dipandang sebelah mata dan kurang diperhitungkan.

${ }^{1}$ Dosen Tetap Sekolah Tinggi Agama Islam Miftahul Huda Al-Azhar (STAIMA) Kota Banjar Jawa Barat.

NO. 1. VOL. I. 2008

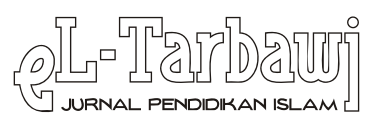


Tidaklah mengherankan bila muncul di masyarakat stereotyping, bahwa pendidikan Islam selalu diasosiasikan dengan lembaga pendidikan terbelakang, kurang bermutu serta tidak menghasilkan lulusan (educational output) yang memadai dan tidak memiliki kemampuan komprehensif-kompetitif terutama dalam bidang ilmu pengetahuan. (Fahrurrozi, From: http://www.msi-uii.net .,akses, Sabtu, $7 / 6 / 2008$, jam 11.27).

Secara sederhana bisa kita lihat dari rendahnya minat para orang tua untuk menyerahkan masa depan pendidikan anak-anaknya ke madrasah atau pesantren (notabane Islam). Biasanya mereka tidak menjadikan lembaga-lembaga tersebut sebagai alternatif utama untuk menyekolahkan anak-anak mereka. Kalaupun akhirnya mereka masuk bersekolah di madrasah, pesantren ataupun sekolah Islam biasanya itu dilakukan karena terpaksa (karena tidak lulus di sekolah umum, misalnya). Ironi sekali, sebagai bangsa besar dengan penduduk ratusan juta jiwa dengan mayoritas penduduknya beragama Islam. Padahal menurut sebuah perhitungan manusia Muslim Indonesia adalah jumlah pemeluk agama Islam terbesar di dunia. Jika dibanding dengan negara-negara Muslim lainnya, maka penduduk Muslim Indonesia dari segi jumlah tidak ada yang menandingi. Rupaya jumlah besar (mayoritas) bukan semata-mata menjadi lembaga pendidikan Islam yang menjadi sandaran utama dalam upaya pengembangan pendidikan bermutu di Indonesia.

Gambaran di atas, menunjukkan bahwa dunia pendidikan Islam di Indonesia memang begitu dilematis. Artinya di satu sisi, tuntutan untuk meningkatkan mutu dan kualitas agar dapat bersaing dengan lembaga pendidikan umum, di sisi lain perhatian dari pemerintah terhadap lembaga pendidikan Islam masih rendah bahkan masih ditempatkan bukan sebagai kelas utama (the first class) melainkan sebagai kelas kedua (the second class).

\section{B. Perkembangan Lembaga Pendidikan Islam}

Lembaga Pendidikan Islam yang dalam hal ini dapat diwakili oleh pesantren, madrasah dan sekolah Islam. Ketiga institusi pendidikan di atas memiliki nama yang berbeda, akan tetapi memiliki pemahaman yang sama baik secara fungsional dan substansional. Secara fungsional ketiga lembaga pendidikan tersebut sebagai wadah untuk menggembleng mental, moral dan spiritual generasi muda dan anak-anak untuk dipersiapkan menjadi manusia yang berguna bagi agama, nusa dan bangsa. Sedangkan secara substansial dapat 
dikatakan bahwa ketiga institusi tersebut merupakan panggilan jiwa spiritual seorang kyai, ustadz, guru yang tidak semata-mata didasari oleh motif materiil, tetapi sebagai pengabdian kepada Allah. Hal ini sejalan dengan tujuan pendidikan Islam yang diungkapkan oleh Al-Ghozali yaitu mendekatkan diri kepada Allah, bukan semata-mata untuk pangkat maupun bermegah-megahan (Ihsan: 2008).

Untuk memperjelas hal tersebut di atas akan dibahas ketiga lembaga pendidikan Islam yaitu pesantren, madrasah dan sekolah Islam. Karena ketiga lembaga pendidikan tersebut setidaknya mewakili konfigurasi lembaga pendidikan Islam yang hingga kini masih eksis di Indonesia.

\section{Pesantren.}

Pesantren merupakan salah satu lembaga pendidikan tertua di Indonesia dan sejarahnya telah mengakar secara berabad-abad. Sebagai lembaga pendidikan khas Indonesia, khususnya Jawa, pesantren memiliki keunikan tersendiri yang tidak dapat ditemui dalam sejarah peradaban Timur Tengah sekalipun. Menurut Nurcholis Madjid dalam buku beliau yang berjudul Bilik-Bilik Pesantren (Paramadina-Jakarta, 1997) menyebutkan, bahwa pesantren mengandung makna keislaman sekaligus keaslian (indigenous) Indonesia. Kata "pesantren" mengandung pengertian sebagai tempat para santri atau murid pesantren, sedangkan kata "santri" diduga berasal dari istilah sansekerta "sastri" yang berarti "melek huruf", atau dari bahasa Jawa "cantrik" yang berarti orang yang mengikuti gurunya kemanapun pergi. Dari sini dapat dipahami bahwa pesantren setidaknya memiliki tiga unsur, yakni; Santri, Kyai dan Asrama (pondok).(Hamidah, From: http://hildaku.blog. com/614889 diakses Jum'at 6/6/2008 jam 11.23)

Pesantren di Indonesia pada masa penjajahan kolonial Belanda tidak berkembang secara baik. Kebijakan-kebijakan pemerintah Belanda berupaya membatasai dan menghambat perkembangannya. Hal ini dapat dilihat dari kebijakannya pada tahun 1882 pemerintah Belanda mendirikan Priesterreden (Pengadilan Agama) yang bertugas mengawasi kehidupan beragama dan pendidikan pesantren. Berselang tidak begitu lama kemudian, dikeluarkan Ordonansi tahun 1905 yang berisi peraturan bahwa guru-guru agama yang akan mengajar harus mendapatkan izin dari pemerintah setempat. Peraturan yang lebih ketat lagi dibuat pada tahun 1925 yang membatasi siapa yang 
boleh memberikan pelajaran mengaji. Akhirnya, pada tahun 1932 peraturan dikeluarkan yang dapat memberantas dan menutup madrasah dan sekolah yang tidak ada izinnya atau yang memberikan pelajaran yang tak disukai oleh pemerintah. (Dhofier 1985, Zuhairini 1997)

Pada zaman kemerdekaan, perkembangan pesantren juga belum menggembirakan. Pada tahun 1949, setelah penyerahan kedaulatan pemerintah Indonesia justru mendorong pembangunan sekolah umum seluas-luasnya dan membuka secara luas jabatanjabatan dalam administrasi modern bagi bangsa Indonesia terdidik dalam sekolah-sekolah umum tersebut. Dampak kebijakan tersebut mengakibatkan penurunan minat untuk masuk pesantren. ((Dhofier 1985).

Hingga pada tahun 1978 ketika Mukti Ali menjabat menteri Agama terjadi warna baru di lingkungan pesantren yang membawa perjalanan politik kaum santri. Ketika itu Mukti Ali membuat kebijakan untuk memasukkan sekitar 70 persen mata pelajaran umum ke dalam kurikulum madrasah. Berkat pembaharuan di lingkungan pesantren inilah ekuivalensi pendidikan madrasah dengan sekolah umum diakui Badrun. ( http://ubed-centre.blogspot. com akses Senin 16/6/2008). Jumlah pesantren dan santri mulai meningkat. Hal ini dapat dilihat dari tabel berikut:

TABEL : Jumlah pesantren dan santri di Jawa pada tahun 1978. (Laporan Departement Agama RI)

\begin{tabular}{|l|c|c|}
\hline Propinsi Daerah & Jumlah Pesantren & Jumlah Santri \\
\hline Jakarta & 27 & 15767 \\
\hline Jawa Barat & 2237 & 305747 \\
\hline Jawa Tengah & 430 & 65070 \\
\hline Tawa Timur & 1051 & 290790 \\
\hline Jumlah: & $\mathbf{3 7 4 5}$ & $\mathbf{6 7 5} \mathbf{3 6 4}$ \\
\hline
\end{tabular}

(Hasbullah, 1996)

Statistik dari tabel di atas, yang dikumpulkan dari laporan Departemen Agama RI pada tahun 1978 yang mengenai keadaan pesantren di Jawa, menunjukkan bahwa sistem pendidikan pesantren di Jawa dipelihara, dikembangkan dan dihargai oleh masyarakat umat Islam di Indonesia. (Dhofier 1985:20).

Menurut Azra (2005) sejak digulirkannya kebijakan tersebut pesantren berkembang menjadi lembaga yang tidak saja mencakup dengan pendalaman masalah agama (tafaqquh fid-din)dan madrasah tetapi juga pendidikan umum. Bahkan, pesantren juga menjadi pusat pengembangan masyarakat dalam berbagai bidang sejak dari ekonomi 
rakyat. Pesantren tidak lagi hanya terdapat di pedesaan; sejak 1980an, banyak pesantren bermunculan di kawasan perkotaan. Semua itu juga, yang membuat anak-anak lulusan pesantren, sejak 1980an mampu berkompetisi dan sukses melanjutkan pendidikan di mancanegara; tidak hanya di negara-negara Timur Tengah, namun juga di negara-negara Barat. Mereka ini pada gilirannya memperkaya dan memperkuat generasi baru kaum terpelajar dan intelektual Muslim di Indonesia. (Republika, Kamis, 22 Desember 2005 dalam http://ubed-centre.blogspot.com akses Senin 16/6/2008).

Sementara itu dua tahun setelah pemilu pertama rezim Orde Baru, komunitas politisi santri disibukkan dengan kebijakan fusi partai pada 1973. Ketika politisi santri (NU) tersisih dalam percaturan politik PPP yang berlawanan dengan MI-nya H.J Naro, melalui Munas Ulama NU di Situbondo, 21 Desember 1983 memutuskan untuk kembali ke Khitah 1926 dan dikuatkan setahun sesudahnya dalam Muktamar NU di Situbondo, 8-12 Desember 1984. Upaya NU kembali ke Khittah meniscayakan NU tidak berafiliasi kepada partai politik manapun sehingga para politisinya bebas masuk kemana saja. Badrun ( http://ubed-centre.blogspot.com akses Senin 16/6/2008).

Pada awal era reformasi pesantren mengalami peningkatan dan mendapatkan perhatian yang baik dari pemeritah sehingga beberapa pesantren mendapatkan ekuivalensi dengan sekolah umum diakui seperti ditegaskan UU Sisdiknas 1989 sebagaimana juga kemudian masih termuat dalam UU Sisdiknas 2003. Pengakuan pendidikan pesantren dengan pendidikan pada umumnya. Namun semenjak tragedi 11 September 2001, image pesantren mulai "tercoreng". Amerika yang secara gencarnya memerangi terorisme, dengan slogan 'are you with us or with them-terrorist-', terlebih-lebih lembaga-lembaga pendidikan tradisional Islam, seperti madrasah dan belakangan juga pesantren dianggap kalangan Barat tertentu sebagai the breeding ground, tempat perkecambahan radikalisme. Pesantren dan umat Islam kembali termarjinalkan sebagai warga negara. Mereka tercitrakan sebagai ‘tertuduh' dalam berbagai kasus kekerasan di tanah air hanya dikarenakan beberapa oknum pelaku teroris merupakan alumnus pesantren. (Hamidah From: hildaku. blog. Senin 16/6/2008).

\section{Madrasah}

Madrasah adalah salah satu lembaga pendidikan Islam yang penting selain pesantren. Keberadaaanya begitu penting dalam upaya 
meningkat kualitas Sumber Daya Manusia (SDM) dan menciptakan kader-kader bangsa yang memiliki wawasan keislaman dan nasionalisme yang tinggi. Madrasah berupaya mengintegrasikan ilmu agama dan umum. Menyeimbangkan keduanya untuk menggapai kebahagiaan dunia dan akhirat. Q.S. (Al-Qasas (28): 77.

Di Indonesia, permulaan munculnya madrasah baru terjadi sekitar abad ke-20. Meski demikian, latar belakang berdirinya madrasah tidak lepas dari dua faktor, yaitu; semangat pembaharuan Islam yang berasal dari Islam pusat (Timur Tengah) dan merupakan respon pendidikan terhadap kebijakan pemerintah Hindia Belanda yang mendirikan serta mengembangkan sekolah (Maksum, 1999). Berdirinya madrasah tidak terlepas dari adanya kekhawatiran terhadap sekolah-sekolah yang didirikan oleh kolonial belanda yang tidak memasukkan pelajaran agama.

Para penulis sejarah pendidikan Islam di Indonesia agaknya sepakat dalam menyebut beberapa madrasah pada periode pertumbuhan, khususnya di wilayah Sumatera dan Jawa. Mahmud Yunus memasukkan ke dalam madrasah kurun pertumbuhan ini antara lain Adabiah School (1909) dan Diniah School Labai al-Yunusi (1915) di Sumatera Barat, Madrasa Nahdlatul Ulama di Jawa Timur, Madrasah Muhammadiyah di Yogyakarta, Madrasah Tasywiq Thullab di Jawa Tengah, Madrasah Persatuan Umat Islam di Jawa Barat, Madrasah Jami'atul Khair di Jakarta, Madrasah Amiriah Islamiyah di Sulawesi dan Madrasah Assulthaniyah di Kalimantan (Maksum, 1999; Karel Steenbrink, 1986).

Dalam perkembangannya, sistem pendidikan madrasah mengalami perubahan tidak menggunakan sistem pendidikan yang sama dengan pendidikan Islam pesantren. Karena madrasah mulai memasukkan pelajaran-pelajaran umum dan metode yang digunakan tidak lagi dengan metode sorogan atau bandongan, melainkan mengikuti sistem pendidikan modern dengan model klasikal. Dengan demikian, madrasah merupakan sub sistem pendidikan pesantren, semisal yang dilakukan di Tebu Ireng. Pembaharuan sistem tersebut menyebar ke beberapa pesantren semisal di Kediri, Demak, Kudus, Cirebon dan Banten. (Muhaimin:2003).

Perkembangan pendidikan Islam terus mengalami peningkatan secara signifikan. Hal itu dapat dilihat misalnya pada pertengahan dekade 60-an, madrasah sudah tersebar di berbagai daerah di hampir seluruh propinsi Indonesia. Dilaporkan bahwa jumlah madrasah tingkat rendah pada masa itu sudah mencapai 13.057. dengan jumlah ini, sedikitnya 1.927.777 telah terserap untuk mengenyam 
pendidikan agama. Laporan yang sama juga menyebutkan jumlah madrasah tingkat pertama (tsanawiyah) yang mencapai 776 buah dengan jumlah murid 87.932. Adapun jumlah madrasah tingkat Aliyah diperkirakan mencapai 16 madrasah dengan jumlah murid 1.881. Dengan demikian, berdasarkan laporan ini, jumlah madrasah secara keseluruhan sudah mencapai 13.849 dengan jumlah murid sebanyak 2.017.590. Perkembangan ini menunjukkan bahwa sudah sejak awal, pendidikan madrasah memberikan sumbangan yang signifikan bagi proses pencerdasan dan pembinaan akhlak bangsa (Maksum, 1999).

Meskipun pemeritah melalui Departemen Agama telah melakukan perubahan dan perubahan kebijakan dalam berbagai segi untuk memajukan madrasah, namun hal itu belum terlalu berhasil dibandingkan dengan sekolah-sekolah umum yang dikelola oleh Departemen Pendidikan. Realitas ini dapat dicermati hingga periode 90-an masih mempunyai sense of interest yang tinggi untuk masuk ke sekolah-sekolah umum yang dinilainya mempunyai prestise yang lebih baik daripada madrasah / sekolah Islam (Islamic School). Lebih dari itu, dengan masuk ke sekolah-sekolah umum, masa depan siswa akan lebih terjamin ketimbang masuk ke madrasah atau sekolah Islam. Hal itu bisa jadi disebabkan oleh image yang menggambarkan lulusan-lulusan madrasah tidak mampu bersaing dengan lulusanlulusan dari sekolah-sekolah umum. Lulusan madrasah hanya mampu menjadi seorang guru agama atau ustdaz. Sedangkan lulusan dari sekolah umum mampu masuk ke sekolah-sekolah umum yang lebih bonafide dan mempunyai jaminan lapangan pekerjaan yang pasti. (Umam, http:// pendis.depag.go.id/madrasah/Insidex.php, akses Jum'at 6/6/2008).

Dalam konteks kekinian, image madrasah telah berubah. Madrasah tidak lagi menjadi sekolah Islam yang hanya diminati oleh kalangan menengah ke bawah. Melainkan sudah banyak diminati oleh masyarakat dari golongan menengah ke atas. Hal ini disebabkan munculnya madrasah elit yang sejajar dengan sekolahsekolah umum.

\section{Sekolah Islam}

Sejak awal abad ke-20 gagasan modernisasi Islam menemukan momentum. Pendidikan direalisasikan dengan pendirian lembagalembaga pendidikan modern. Gagasan tersebut menuntut adanya modernisasi sistem pendidikan Islam. Perkembangan mencolok 
terjadi pada tahun 90an adalah munculnya sekolah-sekolah Islam elite Muslim yang dikenal sebagai "sekolah Islam". Sekolah-sekolah itu mulai menyatakan diri secara formal dan diakui oleh kalangan Muslim sebagai "sekolah unggulan" atau sekolah Islam unggulan. Sekolah Islam unggulan tersebut seakan menjawab tuntutan modernisasi sistem pendidikan Islam. Zoher http://digilib.itb.ac.id/ gdl.php. akses Jum'at 6/6/2008).

Sekolah-sekolah tersebut dapat dikatakan sebagai sekolah "elite" Islam dikarenakan beberapa hal yang mendasarinya. Menurut Sanaky (2003), alasan yang melatar belakangi sekolah-sekolah tersebut bersifat elite antara lain dari segi akademis. Dalam beberapa kasus, hanya siswa-siswa yang terbaik saja yang dapat diterima. Sedangkan tenaga pengajar (guru) yang mengajar pun hanyalah mereka yang memenuhi kualifikasi yang dipersyaratkan melalui seleksi yang kompetitif. Sekolah-sekolah tersebut dikelola oleh manajemen yang baik dengan berbagai fasilitas yang memadai dan lengkap seperti perpustakaan, ruang komputer, masjid dan sarana olah raga.

Sedangkan menurut Alaydroes, sekolah Islam termasuk sekolah Islam terpadu, memasukkan nilai-nilai Islam dari berbagai saluran. Baik saluran formal dalam arti pembelajaran agama, dan semua mata pelajaran bernuansa Islami, apakah itu IPA, Matematika, Geografi, PMP, itu semua harus dikaitkan dengan nilai-nilai spritual, nilai-nilai Illahiah. Kemudian yang kedua, merekrut guru-guru yang punya visi dan ideologi yang sama, mereka tidak diperkenankan merokok, berakhlak karimah, dan bisa menjadi teladan. Selain itu, perilaku ibadah anak-anak juga dibentuk, lewat sholatnya atau doa-doanya dan diupayakan untuk mengikuti sunnah. (Alaydroes, http://www. pks-anz.org/pkspedia/index.php, akses Jum'at 6/6/2008).

Dari perkembangan sekolah-sekolah ini, pemerintah dalam hal ini Departemen Agama dan para ahli pendidikan mulai percaya akan kualitas yang ditawarkan oleh sekolah "elite", "unggulan". Sehingga ke depan perbedaan (dikotomi) antara pendidikan Islam dan pendidikan umum dalam konfigurasi pendidikan Nasional harus dipersempit. Pendidikan Islam harus diberikan kesempatan untuk meningkatkan kualitas dan yang seimbang untuk mewujudkan pendidikan bermutu sejajar dengan pendidikan umum.

\section{Peran Lembaga Pendidikan Islam}

Perkembangan lembaga pendidikan Islam di tidak bisa dikatakan 
berhenti ditempat (stagnan). Peran lembaga pendidikan Islam di Indonesia sangat signifikan. Hal ini dibuktikan dengan eksistensi lembaga pendidikan Islam semenjak masa pra kemerdekaan, kemerdekaan hingga masa reformasi. Dapat dilihat dari peran dan kontribusi lembaga pendidikan Islam dalam berbagai aspek :

1. Aspek pendidikan (pedagogis). Sebagai lembaga yang bergerak dalam dunia pendidikan, lembaga pendidikan Islam berperan penting dalam peningkatan SDM yang berkualitas dan melahirkan kader-kader pemimpin bangsa yang memiliki wawasan keislaman dan nasionalisme yang tinggi. Semisal Nurcholis Madjid (alm), Abdurrahman Wahid, Amin Rais, Hidayat Nurwahid, Hamzah Haz, Jusuf Kalla, Alwi Shihab, Nurmahmudi Ismail, Yusril Ihza Mahendra, Muhaimin Iskandar, Efendi Choeri, Anas Urbaningrum dll adalah fenomena politisi yang lahir dari lembaga pendidikan Islam di Indonesia.

2 Aspek Moral-Spiritual. Pendidikan Islam bertujuan membina peserta didik menjadi hamba yang suka beribadah kepada Allah. (Ihsan: 2003). Lembaga pendidikan Islam berupaya memberikan penguatan dan dasar pemahaman keagaamaan secara baik. Mengajarkan nilai-nilai kejujuran, kerendahan hati, kesederhanaan dan nilai-nilai keluruhan kemanusiaan. Nilai keluhuran itulah yang mengantarkan peserta didik mendapat penilaian yang baik di sisi masyarakat dan di mata Tuhan-Nya.

3. Aspek sosio-kultural. Tidak dapat dipungkiri lembaga pendidikan Islam memberikan pengaruh yang signifikan terhadap corak dan karekter masyarakat. Merespons persoalan-persoalan masyarakat seperti memelihara tali persaudaraan, menciptakan kehidupan yang sehat dan sebagainya. Hal ini sebagaimana yang diungkapkan oleh KH. Abdurrahman Wahid (2002) ketika melihat pesantren (notabane lembaga pendidikan Islam) sebagai "lembaga kultural" yang menggunakan simbol-simbol budaya jawa; sebagai "agen pembaharuan" yang memeperkenalkan gagasan pembangunan pedesaan (rural development); sebagai pusat kegiatan belajar masyarakat (centre of community learning).

\section{D, Penutup}

Sebagai catatan akhir, terlepas dari banyaknya problem dan stereotyping yang melekat pada lembaga pendidikan berbasis Islam, peranannya tidak dapat diabaikan dan dilihat sebelah mata. Bagaimanapun juga, harus kita akui bahwa pendidikan Islam telah 
berperan dan memberikan kontribusi yang signifikan dalam upaya peningkatan SDM yang berkualitas di Indonesia. Oleh karena itulah hendaknya Pemerintah dalam hal ini Departemen Agama maupun Departemen Pendidikan menghilangkan "dikotomi" atau "diskrit" dalam memandang lembaga pendidikan Islam. Tindakan membedakan serta mengkotak-kotakkan pendidikan "umum" dan agama hanyalah akan menimbulkan kerancuan dan kesenjangan pendidikan di Indonesia.

Sedangkan lembaga-lembaga pendidikan Islam dalam upaya mempertahankan peran dan eksistensinya harus mampu melakukan pembenahan dan pembaharuan dengan cara: program lembaga-lembaga pendidikan Islam lebih diorentasikan kepada penguasaan ilmu pengetahuan dan teknologi serta pengembangan ketrampilan dengan meningkatkan kemampuan untuk menggunakan menggunakan berbagai teknologi elektrik. Lembaga-lembaga pendidikan Islam harus mampu mengembangkan atau melakukan depresivikasi program-program bidang studi yang sesuai dengan kebutuhan tenaga di bidang-bidang tertentu atau sesuai dengan kurikulum dan silabi relevan dengan kompetensi mencakup spiritual, illahiyah, knowledge, skill, ability dan kultural-sosial yang diarahkan pada kebutuhan pasar. (Sanaky:2003)

\section{DAFTAR PUSTAKA}

Alaydroes, Fahmi. Liputan Media. From: http://www.pks-anz.org/pkspedia/ index.php, akses Jum'at 6/6/2008).

Badrun, Ubedilah. Pesantren dan Kepemimpinan Nasional. From: http://ubed-centre.blogspot.com, akses 16/6/2008.

Dhofier, Zamakhsyari. (1985). Tradisi Pesantren: Studi Tentang Pandangan Hidup Kyai, LP3ES, Jakarta.

Fahrurozi. Resensi Buku: Menata Ulang Konsep dan Praktik Pendidikan Islam. From: http://www.MsI-UII.Net .,akses, Sabtu, 7/6/2008, jam 11.27.

Hamidah,Kamila. Sejarah Pesantren dan Radikalisme Islam. http:// hildaku.blog.com/ diakses Jum'at 6/6/2008 jam 11.23.

Hasbullah. (1996). Sejarah Pendidikan Islam di Indonesia Lintas Sejarah Pertumbuhan dan Perkembangan. Jakarta: PT. Raja Grafindo Persada.

Ihsan, Hamdani \& Fuad. (2007). Filsafat Pendidikan Islam.Bandung:

Pustaka Setia. 
Madjid, Nurcholis.(1997). Bilik-Bilik Pesantren. Jakarta: Paramadina

Muhaimin.(2003). Arah Baru Pengembangan Pendidikan Islam. Bandung. Nuansa.

Umam, Khoirul. Madrasah dan Globalisasi. From: http://pendis.depag. go.id/madrasah/ akses Jum'at 6/6/2008).

Sanaky, Hujair AH. (2003).Paradigma Pendidikan Islam: Membangun Masyarakat Madani Indonesia, Yogyakarta: Safira Insania Press.

Wahid, Abdurrahman." Pendidikan Islam Harus Beragam". Kedaulatan Rakyat 21 Desember 2002.

Zoher, Abdul Quddus. Menggagas dan mewujudkan Sekolah Unggul atau Sekolah Model (Upaya modernisasi sistem pendidikan Islam di Indonesia. From: http://digilib.itb.ac.id/gdl.php akses Jum'at 6/6/2008.

Zuhairini, Dra., dll., 1997, Sejarah Pendidikan Islam, Bumi Aksara, Jakarta. 